\title{
The humanistic, economic and societal burden of Herpes Zoster in Europe: a critical review
}

Adam Gater $^{1 *}$, Mathieu Uhart ${ }^{2}$, Rachael McCool ${ }^{1}$ and Emmanuelle Préaud ${ }^{2}$

\begin{abstract}
Background: Herpes zoster $(\mathrm{HZ})$ or "shingles" is common in persons aged 50 years or over. $\mathrm{HZ}$ is characterised by a painful dermatological rash which typically resolves in approximately one month. Persistent pain for months or years after rash onset, however, is a common complication of $\mathrm{HZ}$; referred to as post-herpetic neuralgia (PHN). Both $\mathrm{HZ}$ and PHN have a significant impact on patients' lives, with considerable implications for healthcare systems and wider society. The aim of the present review is to provide comprehensive documentation and critical appraisal of published data concerning the humanistic, economic and societal burden of $\mathrm{HZ}$ in Europe.

Methods: Systematic literature searches were conducted in Medline, EMBASE, PsycINFO, EconLit, HEED and CRD databases. Searches were conducted in July 2014 and restricted to articles published in the past 20 years. Articles were selected for full review by two independent researchers in accordance with predefined eligibility criteria.

Results: From a review of 1619 abstracts, 53 eligible articles, were identified which reported data concerning healthcare resource use $(n=38)$, direct costs $(n=20)$, indirect costs $(n=16)$, total costs $(n=10)$ and impact on health-related quality of life (HRQOL) $(n=21)$. Findings highlight that PHN is associated with greater impairments in HRQoL and higher costs of management than $\mathrm{HZ}$. For both $\mathrm{HZ}$ and PHN, pain severity is a significant predictor of impact on individuals, healthcare systems and society. While the incidence of $\mathrm{HZ}$ and PHN increase with age, age does not appear to be a key driver of overall costs for HZ and PHN. Specifically, while direct costs (e.g. GP, specialists, medications, hospitalisations) tend to be higher for older patients, indirect costs (e.g. work time missed) are higher for younger patients.
\end{abstract}

Conclusions: Available evidence highlights that $\mathrm{HZ}$ and PHN result in significant humanistic and economic burden for patients, healthcare systems and wider societies. A tendency to focus upon healthcare resource use and the direct costs of management at the expense of other impacts (e.g. informal caregivers and formal social care) may result in an underestimation of the true burden of $\mathrm{HZ}$ and PHN.

\section{Background}

Herpes zoster (HZ), also known as shingles, is caused by the reactivation of the varicella zoster virus (VZV). Primary infection with VZV usually occurs during childhood, manifesting as chickenpox, after which the virus lies dormant [1]. The great majority (95\%) [2] of the population hosts VZV and approximately one in four persons will develop $\mathrm{HZ}$ in their lifetime through reactivation, leading to an estimated 1.7 million episodes in Europe annually [3]. VZV reactivation is primarily related to an age-related decline in VZV-specific immunity; it is

\footnotetext{
* Correspondence: adam.gater@adelphivalues.com

'Adelphi Values, Adelphi Mill, Grimshaw Lane, Bollington, Cheshire SK10 5JB, UK

Full list of author information is available at the end of the article
}

well documented that the incidence of $\mathrm{HZ}$ increases with age, with the majority of cases occurring in patients over 50 years of age [4].

$\mathrm{HZ}$ is characterized by a painful dermatomal rash, which most commonly presents on the trunk and lumbar regions. HZ, however, may present along any nerve including the ophthalmic division of the trigeminal nerve where it can affect the eye. Herpes Zoster Ophthalmicus (HZO) occurs in $10-20 \%$ of all $\mathrm{HZ}$ cases and in some cases can lead to ocular complications [5].

The dermatological rash and pain associated with $\mathrm{HZ}$ typically resolves within one month of presentation [4]; however, long-term complications can arise. Post-herpetic neuralgia (PHN) is the most common and debilitating complication of HZ, occurring in approximately $10-20 \%$ 
of all sufferers [6-8] and as many as 50\% of those aged 85 years and over [9]. PHN is a neuropathic syndrome manifesting as on-going pain along the nerves in the area of the prior $\mathrm{HZ}$ rash and typically involves one or more of the following: spontaneous aching or burning; paroxysmal shooting pains; allodynia, and hyperalgesia $[9,10]$. There is no consensus regarding the definition of PHN; however, PHN is often defined as pain persisting for 90 days from $\mathrm{HZ}$ rash onset $[4,6,10,11]$. While $\mathrm{HZ}$ is an acute experience that typically resolves within one month, in the majority of sufferers, PHN persists for at least 6 months with some patients experiencing PHN for years [12-15]. As expected given the relationship to $\mathrm{HZ}$, the incidence of PHN increases markedly with age [16-18]. The incidence of PHN is also linked to the severity of pain experienced during the prior $\mathrm{HZ}$ episode (among other predictors such as the severity of the dermatomal rash and prodromal symptoms) [19], with those patients experiencing the highest levels of pain during $\mathrm{HZ}$ presentation being most at risk of developing PHN [20].

As conditions primarily affecting older persons, many patients with $\mathrm{HZ}$ and PHN may already experience significant deficits in health status. Findings from a number of articles indicate that the pain and resulting discomfort associated with $\mathrm{HZ}$ and PHN can have a substantial negative and widespread impact on patients' healthrelated quality of life (HRQoL) and patients' ability to engage in activities of daily living [7,20-25]. In addition to the burden encountered by the individual with $\mathrm{HZ}$, the condition is also associated with considerable economic burden. For example, considerable costs to healthcare systems [26-31] arise from the care provision for $\mathrm{HZ}$ and PHN patients, including visits to primary care (general practitioner) and outpatient secondary/tertiary care (specialist pain clinics and ophthalmologists), inpatient visits (hospitalisations) and prescription costs. Furthermore, $\mathrm{HZ}$ and PHN are also associated with significant indirect costs, primarily in terms of loss of productivity for younger patients $[7,21,23,24,28,32]$. Finally, as conditions occurring in retired and older patients, $\mathrm{HZ}$ and PHN can also have significant consequences for the caregivers of patients including partners, relatives, and friends of people with the conditions [7]. Such details, however, may often go unreported and are not often communicated in the research literature.

Evidence for the efficacy of a VZV vaccine in the prevention of $\mathrm{HZ}$ and $\mathrm{PHN}$ episodes and attenuation of the severity of $\mathrm{HZ}$ and PHN episodes and associated impact has been documented in recent years $[11,33]$. In order to understand the value of preventative strategies, a complete understanding of the impact of $\mathrm{HZ}$ and $\mathrm{PHN}$ is required. While a significant body of literature has sought to determine the impact of $\mathrm{HZ}$ and PHN on patients, healthcare systems and wider society within EU countries, to date, no comprehensive review of these studies has been conducted. The aim of this review, therefore, is to provide a comprehensive and holistic overview of the humanistic, economic and societal burden of HZ and PHN in Europe as reported within the published peer-reviewed literature.

\section{Methods}

Published peer-reviewed articles were identified via systematic searches conducted in the following biomedical and economic databases: EMBASE, Medline, PsycINFO, EconLit, Health Economic Evaluations Database (HEED) and the Centre for Reviews and Dissemination databases at the University of York. Searches and reviews were conducted in accordance with the Cochrane systematic review guidelines [34]. A range of disease-related, economic, societal and HRQoL-related keywords was utilized to capture the humanistic, economic and societal burden of HZ and PHN (see Table 1). Searches were conducted in July 2014 and were restricted to articles published in the last 20 years. Although data relating to the EU was the primary focus of this review, no limits regarding study country or article language were implemented during the search stage (so to not exclude potentially relevant articles). Instead, articles focused on the EU were prioritized as part of the article selection process.

In accordance with Cochrane review guidelines [35], all abstracts were reviewed by two researchers independently according to formal inclusion/exclusion criteria (Table 2). For inclusion in the review, abstracts were required present information specific to adult patients in the EU and to contain information pertaining to the key search terms (see Table 1). In instances were aforementioned details were not clear from the abstract, full text articles were obtained to confirm whether the article should be included/excluded. Real world data, observational studies, effectiveness studies, qualitative studies, economic evaluations and cost studies were all considered relevant for review. The final list of abstracts and articles for full in-depth review was agreed following consensus between the authors.

Data extraction tables were developed to accurately record information from the articles chosen for review. Of importance was information related to the study aims, design and outcomes of interest, sample characteristics, country of study, resource use data, cost data (direct and indirect) and any patient-reported impacts of $\mathrm{HZ}$ and PHN. All referenced costs are provided in Euros and have been adjusted to the same price year (2015) based on annual average rate of change (\%) in the Harmonised Index of Consumer Prices [36]. 
Table 1 Search terms

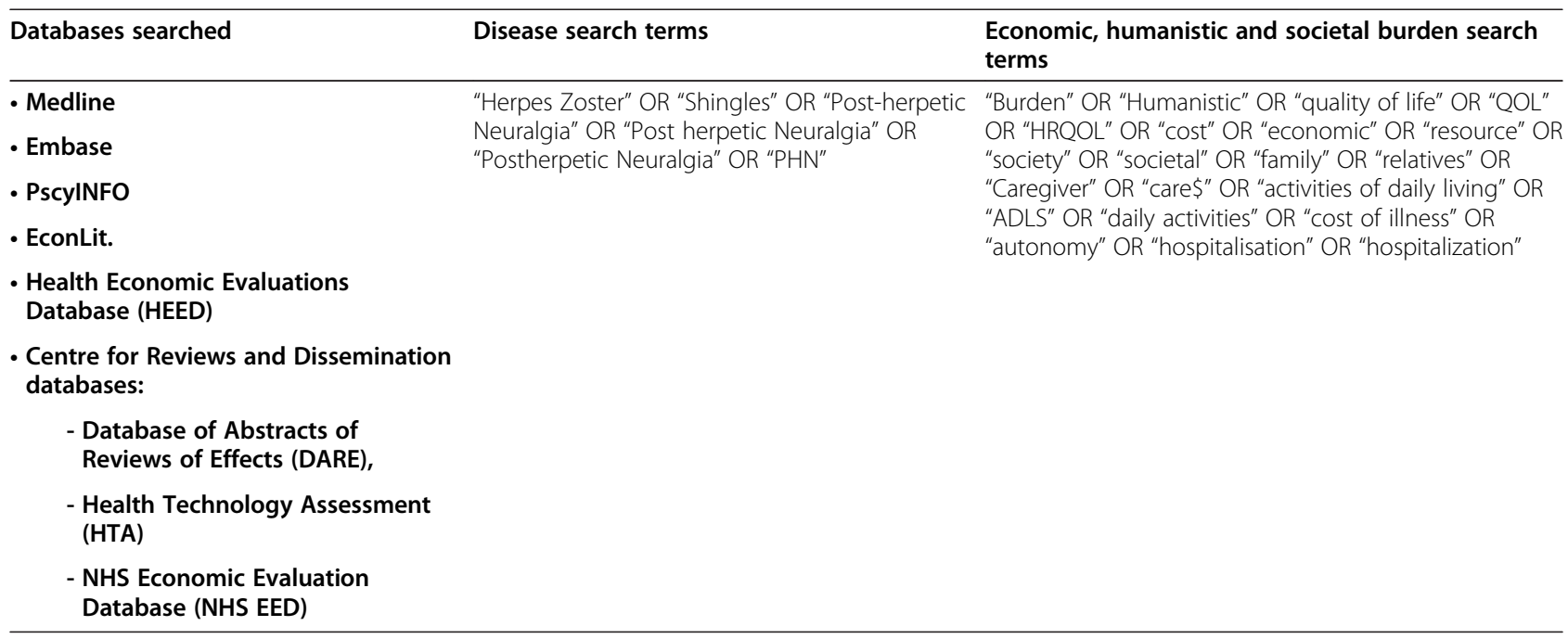

\section{Results}

Search results

Figure 1 provides an overview of the article selection process. A total of 1619 titles and abstracts were reviewed against the inclusion/exclusion criteria, resulting in $78 \mathrm{EU}$ based articles for full text review. A further 25 articles were excluded following full text review, leaving a total of 53 studies to be included in this review.

\section{Overview of selected articles}

A summary of the 53 articles selected for inclusion in the review (including study countries, population, data presented) is provided in Table 3.

The references selected for review presented data from 14 European countries with the majority $(n=39,73.6 \%)$ of articles providing data from the 'Big 5' EU countries (UK; Spain; France; Germany \& Italy). Of the included references, 39 reported data specifically attributed to $\mathrm{HZ}$ patients and 35 reported data specifically attributed to PHN patients. Data attributed to a combined HZ and
PHN population was included in 15 references. The references eligible for inclusion in the study were all published between 2000 and 2014.

Data presented in reviewed references was categorized as follows: 1) Healthcare utilisation in terms of rates of medical visits, hospitalisations and medication prescribed, 2) Direct costs corresponding to the management of HZ/PHN, 3) Indirect costs, 4) Total costs and 5) Health related quality of life and humanistic burden. Of note, some references contained data pertaining to multiple categories.

\section{Healthcare utilisation}

Information regarding healthcare resource was included in 38 of the identified references (as summarized in Table 3). Data indicated that HZ and PHN are associated with considerable healthcare utilisation, with increased resource use associated with increasing age and the presence of PHN. Data concerning healthcare utilisation was presented in terms of rates of medical visits (including

Table 2 Study Inclusion/exclusion criteria

\begin{tabular}{|c|c|c|}
\hline & Inclusion criteria & Exclusion criteria \\
\hline Country setting & Present data from a country in the EU or EU in general & $\begin{array}{l}\text { Only present data from a non-EU country. No data } \\
\text { specific to the EU. }\end{array}$ \\
\hline \multirow[t]{2}{*}{ Population } & Adults with $\mathrm{HZ}$ or PHN & Focus mainly on chicken pox \\
\hline & & Immunodepressed patients only (e.g. HIV patients) \\
\hline \multirow[t]{3}{*}{ Study design } & $\begin{array}{l}\text { Real world data, observational studies, effectiveness, } \\
\text { qualitative research and cost studies }\end{array}$ & $\begin{array}{l}\text { Clinical trials of efficacy and safety of treatments } \\
\text { presenting QoL data as secondary endpoint only }\end{array}$ \\
\hline & & Clinical trials of Zostavax \\
\hline & & Focus mainly on epidemiological evidence (e.g. incidence, prevalence etc.) \\
\hline
\end{tabular}




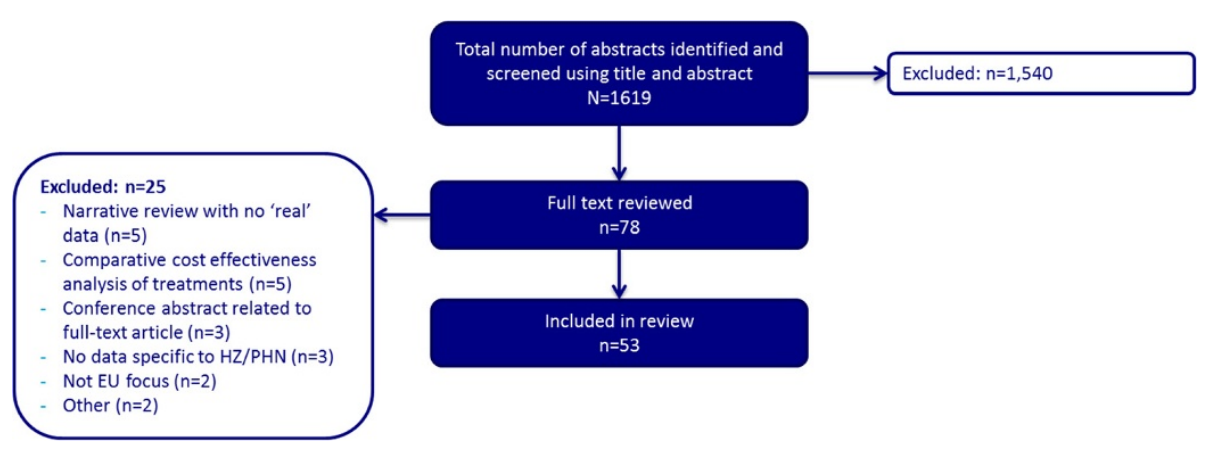

Figure 1 Overview of study selection for review.

GP and specialist visits), hospitalisations (including duration of stay), use of medications and additional diagnostic/laboratory procedures.

\section{Medical visits}

The majority of patients presenting with $\mathrm{HZ}$ will consult their GP at least once [43,50]. Reflecting the chronic nature of PHN, higher rates of medical visits (GP and specialist visits) have been reported in PHN patients compared to $\mathrm{HZ}$ patients $[14,21,27,29,50]$. For example, reports from a study in Italy indicated that patients over the age of 50 with $\mathrm{HZ}$ made approximately 1.9 visits to their GP. By contrast, the reported number of visits among patients with PHN was 11.9 and 12.0 (PHN1 month and PHN 3-months definitions, respectively) [29]. The proportion of patients referred to specialists (74\% PHN versus 18\% HZ) and the number of specialist visits per case (3.5 and 3.9 for PHN-1 month and PHN 3-months vs 0.2 for $\mathrm{HZ}$ ) were also higher for PHN patients compared to $\mathrm{HZ}$ patients. More frequent specialist visits have also been reported among patients with $\mathrm{HZO}$ compared to those with HZ [21].

The average annual incidence of herpes zoster GPconsultations has been reported to increase with age from $32.8 / 10,000$ among those aged $<60$ years, to 93.1 and 113.2/10,000 among those aged 60-64 years and $\geq 65$ years respectively [64]. Similarly, the average number of specialist visits was also higher in patients over the age of 50 compared to those over the age of 14 [27].

\section{Hospitalisations}

The rates of hospitalisations due to $\mathrm{HZ}$ and/or PHN reported in the literature (generally derived from national or insurance databases of hospital admissions) suggest that increased rates of hospitalisation are also associated with increasing age $[55,71]$. More frequent hospitalisations have also been observed among patients with PHN when compared to patients with $\mathrm{HZ}$ across studies in Italy [29], Belgium [40], France [55], Germany [73], Spain $[37,45,49,51,52,61]$. and Portugal [59]. There are also reports of a greater rate of hospitalisations among female $\mathrm{HZ}$ patients compared to male $\mathrm{HZ}$ patients at across all age groups [71].

The average length of inpatient stay for PHN (10.2 \pm 8.6 days) has been reported to be higher than those associated with $\mathrm{HZ}(7.8 \pm 5.4$ days $)$ [29]. The average duration of stay in hospital among $\mathrm{HZ}$ patients also appears to be influenced by age $[47,74]$. For example, analysis of Hospital Episode Statistics (2002-2005) from England indicates the average length of stay among HZ/PHN patients aged 60-64 is 9.3 days whereas those aged 85-90 is 22.3 days [74]. Comparisons between $\mathrm{HZ}$ and $\mathrm{HZO}$ patients over 50 years of age also indicate longer hospital stays in patients with HZO (9.8 vs 7.8 days) [38].

\section{Medication use}

It is reported that up to $100 \%$ of PHN patients and 83.2\% of patients with $\mathrm{HZ}$ receive medication for their condition across all ages [31]. Polypharmacy is common among $\mathrm{HZ}$ patients with $\mathrm{HZ}$ patients reported to be taking at least 4 different medications on average and PHN patients reported to be taking 5 medications [50]. This could potentially have wider implications as polypharmacy is known to be a major cause of drug interactions and issues with treatment adherence and safety [78].

The types of medication used has been reported to vary depending on the population being considered ( $\mathrm{HZ}$ or PHN) $[14,21,29,50]$. Indeed, current treatment of $\mathrm{HZ}$ aims to relieve pain, to limit the spread and duration of the dermatomal lesions and (when started within 72 hours of rash onset) to prevent or alleviate complications associated with HZ. By contrast, for PHN, the focus of medications is to alleviate pain $[79,80]$.

The amount of available information regarding medication use in EU countries was somewhat limited; however available evidence from the literature suggests that, despite the availability of European Guidelines for the management of $\mathrm{HZ}[80,81]$, medication prescribing practices (for the treatment of $\mathrm{PHN}$ in particular) are not consistent across countries $[14,21,25,29,44,50]$. An 
Table 3 Overview of included studies

\begin{tabular}{|c|c|c|c|c|c|c|c|c|c|c|c|}
\hline \multirow[t]{2}{*}{ Author and year } & \multirow{2}{*}{$\begin{array}{l}\text { Country } \\
\text { perspective }\end{array}$} & \multicolumn{5}{|c|}{ Population } & \multirow{2}{*}{$\begin{array}{l}\text { Healthcare } \\
\text { utilisation }\end{array}$} & \multicolumn{3}{|c|}{ Economic data } & \multirow[t]{2}{*}{ HRQol } \\
\hline & & $\mathrm{HZ}$ & $\begin{array}{l}\mathrm{HZ} \text { and } \\
\mathrm{PHN}\end{array}$ & PHN1 & PHN3 & $\begin{array}{l}\text { PHN Other/ } \\
\text { Undefined }\end{array}$ & & $\begin{array}{l}\text { Direct } \\
\text { costs }\end{array}$ & $\begin{array}{l}\text { Indirect } \\
\text { costs }\end{array}$ & $\begin{array}{l}\text { Total } \\
\text { costs }\end{array}$ & \\
\hline Annemans et al. (2010) [26] & Belgium & $\checkmark$ & $x$ & $\checkmark$ & $\checkmark$ & $x$ & $\checkmark$ & $\checkmark$ & $\checkmark$ & $\checkmark$ & $x$ \\
\hline Bayas et al. (2011) [37] & Spain Catalonia & $x$ & $\checkmark$ & $x$ & $x$ & $x$ & $\checkmark$ & $\checkmark$ & $x$ & $x$ & $x$ \\
\hline $\begin{array}{l}\text { Berrut, G. and C. Baptiste } \\
\text { (2013) [38] }\end{array}$ & France & $\checkmark$ & $x$ & $x$ & $x$ & $x$ & $\checkmark$ & $x$ & $x$ & $x$ & $x$ \\
\hline Blein, C., et al. (2013) [39] & France & $\checkmark$ & $x$ & $x$ & $x$ & $x$ & $\checkmark$ & $x$ & $x$ & $x$ & $x$ \\
\hline Bilcke et al. (2012) [40] & Belgium & $x$ & $\checkmark$ & $x$ & $\checkmark$ & $x$ & $\checkmark$ & $\checkmark$ & $\checkmark$ & $x$ & $x$ \\
\hline Bouhassira et al. (2012) [15] & France & $\checkmark$ & $\checkmark$ & $x$ & $\checkmark$ & $x$ & $x$ & $x$ & $x$ & $x$ & $\checkmark$ \\
\hline Bresse, X., et al. (2013) [41] & France & $\checkmark$ & $x$ & $x$ & $\checkmark$ & $x$ & $\checkmark$ & $x$ & $x$ & $x$ & $x$ \\
\hline Bricout, H., et al. (2013) [42] & Italy & $\checkmark$ & $x$ & $x$ & $x$ & $x$ & $x$ & $x$ & $\checkmark$ & $x$ & $\checkmark$ \\
\hline Bricout, H., et al. (2013) [42] & Italy & $\checkmark$ & $x$ & $x$ & $\checkmark$ & $x$ & $\checkmark$ & $x$ & $x$ & $x$ & $\checkmark$ \\
\hline Brisson et al. (2003) [43] & England \& Wales & $x$ & $\checkmark$ & $x$ & $x$ & $\checkmark$ & $\checkmark$ & $\checkmark$ & $\checkmark$ & $\checkmark$ & $x$ \\
\hline $\begin{array}{l}\text { Castro-Lopes, J. M., } \\
\text { et al. (2013) [44] }\end{array}$ & Portugal & $x$ & $x$ & $x$ & $x$ & $\checkmark$ & $\checkmark$ & $x$ & $x$ & $x$ & $\checkmark$ \\
\hline Cebrian-Cuenca et al. (2011) [27] & Spain, Valencia & $\checkmark$ & $x$ & $\checkmark$ & $\checkmark$ & $x$ & $\checkmark$ & $\checkmark$ & $\checkmark$ & $\checkmark$ & $x$ \\
\hline Chidiac et al. (2001) [21] & France & $\checkmark$ & $\checkmark$ & $x$ & $x$ & $\checkmark$ & $\checkmark$ & $x$ & $x$ & $x$ & $\checkmark$ \\
\hline De Juanes et al. (2011) [45] & Spain Madrid & $x$ & $\checkmark$ & $x$ & $x$ & $\checkmark$ & $\checkmark$ & $\checkmark$ & $x$ & $x$ & $x$ \\
\hline Di Legami et al. (2007) [46] & Italy - Piemonte & $\checkmark$ & $x$ & $x$ & $x$ & $\checkmark$ & $\checkmark$ & $\checkmark$ & $x$ & $x$ & $x$ \\
\hline Edmunds et al. (2001) [47] & England and Wales & $x$ & $\checkmark$ & $\checkmark$ & $x$ & $x$ & $\checkmark$ & $\checkmark$ & $x$ & $x$ & $x$ \\
\hline Franco, E., et al. (2013) [48] & Italy & $\checkmark$ & $x$ & $x$ & $\checkmark$ & $x$ & $\checkmark$ & $x$ & $x$ & $x$ & $\checkmark$ \\
\hline Garcia-Doval et al. (2010) [49] & Spain & $\checkmark$ & $x$ & $x$ & $x$ & $\checkmark$ & $\checkmark$ & $x$ & $x$ & $x$ & $x$ \\
\hline Gater, A., et al. (2014) [50] & UK & $\checkmark$ & $x$ & $x$ & $x$ & $x$ & $\checkmark$ & $x$ & $x$ & $x$ & $\checkmark$ \\
\hline Gauthier et al. (2009) [28] & UK & $\checkmark$ & $x$ & $\checkmark$ & $\checkmark$ & $x$ & $\checkmark$ & $\checkmark$ & $x$ & $x$ & $\checkmark$ \\
\hline Gialloreti et al. (2010) [29] & Italy & $\checkmark$ & $x$ & $\checkmark$ & $\checkmark$ & $x$ & $\checkmark$ & $\checkmark$ & $\checkmark$ & $\checkmark$ & $x$ \\
\hline Gil et al. (2004) [51] & Spain & $\checkmark$ & $x$ & $x$ & $x$ & $x$ & $\checkmark$ & $\checkmark$ & $x$ & $x$ & $x$ \\
\hline Gil et al. (2009) [52] & Spain & $\checkmark$ & $x$ & $x$ & $x$ & $x$ & $\checkmark$ & $\checkmark$ & $x$ & $x$ & $x$ \\
\hline Gil-Prieto et al. (2011) [53] & Spain & $\checkmark$ & $x$ & $x$ & $x$ & $x$ & $\checkmark$ & $\checkmark$ & $x$ & $x$ & $x$ \\
\hline Gil-Prieto, R., et al. (2014) [54] & Spain & $\checkmark$ & $x$ & $x$ & $x$ & $x$ & $\checkmark$ & $x$ & $x$ & $x$ & $x$ \\
\hline Gonzalez et al. (2010) [55] & France & $\checkmark$ & $x$ & $x$ & $x$ & $x$ & $\checkmark$ & $x$ & $x$ & $x$ & $x$ \\
\hline Lionis et al. (2011) [56] & Greece & $\checkmark$ & $x$ & $\checkmark$ & $x$ & $x$ & $x$ & $x$ & $x$ & $x$ & $\checkmark$ \\
\hline Loncar, Z., et al. (2013) [57] & Croatia & $\checkmark$ & $x$ & $x$ & $x$ & $x$ & $\checkmark$ & $x$ & $x$ & $x$ & $\checkmark$ \\
\hline Lukas et al. (2012) [58] & $\begin{array}{l}\text { Germany, Spain, } \\
\text { Portugal, the } \\
\text { Netherlands, } \\
\text { Belgium, Sweden } \\
\text { and Switzerland }\end{array}$ & $\checkmark$ & $\checkmark$ & $x$ & $\checkmark$ & $x$ & $x$ & $x$ & $\checkmark$ & $x$ & $\checkmark$ \\
\hline $\begin{array}{l}\text { Mesquita, M. and F. Froes } \\
\text { (2013) [59] }\end{array}$ & Portugal & $\checkmark$ & $x$ & $x$ & $x$ & $x$ & $\checkmark$ & $x$ & $x$ & $x$ & $x$ \\
\hline Mick et al. (2010) [30] & France & $x$ & $\checkmark$ & $x$ & $\checkmark$ & $x$ & $\checkmark$ & $\checkmark$ & $\checkmark$ & $\checkmark$ & $x$ \\
\hline Moore et al. (2010) [60] & UK & $x$ & $\checkmark$ & $\checkmark$ & $\checkmark$ & $x$ & $x$ & $x$ & $\checkmark$ & $x$ & $x$ \\
\hline $\begin{array}{l}\text { Morant-Talamante, N., et al. } \\
\text { (2013) [61] }\end{array}$ & Spain & $\checkmark$ & $x$ & $x$ & $x$ & $x$ & $\checkmark$ & $x$ & $x$ & $x$ & $x$ \\
\hline Mordarski et al. (2009) [62] & Poland & $x$ & $x$ & $x$ & $x$ & $\checkmark$ & $x$ & $x$ & $x$ & $x$ & $\checkmark$ \\
\hline Nilsson, J., et al. (2013) [63] & Sweden & $x$ & $\checkmark$ & $x$ & $x$ & $x$ & $x$ & $x$ & $\checkmark$ & $\checkmark$ & $x$ \\
\hline Pierik et al. (2012) [64] & $\begin{array}{l}\text { Holland/the } \\
\text { Netherlands }\end{array}$ & $\checkmark$ & $x$ & $x$ & $x$ & $x$ & $\checkmark$ & $x$ & $x$ & $x$ & $x$ \\
\hline Rabaud, C., et al. (2013) [65] & France & $\checkmark$ & $x$ & $\checkmark$ & $\checkmark$ & $x$ & $\checkmark$ & $x$ & $x$ & $x$ & $\checkmark$ \\
\hline
\end{tabular}


Table 3 Overview of included studies (Continued)

\begin{tabular}{|c|c|c|c|c|c|c|c|c|c|c|c|}
\hline Rehm et al. (2010) [66] & $\begin{array}{l}14 \text { European countries } \\
\text { (countries not specified) }\end{array}$ & $x$ & $x$ & $\checkmark$ & $x$ & $x$ & $x$ & $x$ & $x$ & $x$ & $\checkmark$ \\
\hline Schiffner-Rohe et al. (2011) [67] & Germany & $\checkmark$ & $x$ & $\checkmark$ & $x$ & $x$ & $\checkmark$ & $\checkmark$ & $x$ & $\checkmark$ & $x$ \\
\hline Scott et al. (2003) [68] & UK & $\checkmark$ & $x$ & $x$ & $\checkmark$ & $x$ & $x$ & $x$ & $x$ & $x$ & $\checkmark$ \\
\hline Scott et al. (2006) [7] & UK & $x$ & $\checkmark$ & $x$ & $\checkmark$ & $x$ & $x$ & $x$ & $\checkmark$ & $\checkmark$ & $\checkmark$ \\
\hline Serpell, M., et al. (2014) [14] & UK & $x$ & $x$ & $x$ & $\checkmark$ & $x$ & $\checkmark$ & $x$ & $x$ & $x$ & $\checkmark$ \\
\hline Sicras-Mainar et al. (2012) [69] & Spain & $\checkmark$ & $\checkmark$ & $x$ & $x$ & $\checkmark$ & $\checkmark$ & $\checkmark$ & $\checkmark$ & $\checkmark$ & $x$ \\
\hline Souliotis, K., et al. (2013) [70] & Greece & $x$ & $\checkmark$ & $x$ & $x$ & $x$ & $x$ & $\checkmark$ & $\checkmark$ & $x$ & $x$ \\
\hline Studahl, M., et al. (2013) [71] & Sweden & $\checkmark$ & $x$ & $x$ & $x$ & $x$ & $\checkmark$ & $x$ & $x$ & $x$ & $x$ \\
\hline Szucs (2011) [72] & Switzerland & $\checkmark$ & $x$ & $x$ & $\checkmark$ & $\checkmark$ & $x$ & $\checkmark$ & $\checkmark$ & $\checkmark$ & $x$ \\
\hline Ultsch et al. (2011) [73] & Germany & $\checkmark$ & $x$ & $x$ & $\checkmark$ & $x$ & $\checkmark$ & $x$ & $x$ & $x$ & $x$ \\
\hline Ultsch et al. (2012) [31] & Germany & $\checkmark$ & $x$ & $x$ & $\checkmark$ & $x$ & $\checkmark$ & $\checkmark$ & $\checkmark$ & $\checkmark$ & $x$ \\
\hline Van Hoek et al. (2009) [74] & England and Wales & $\checkmark$ & $x$ & $x$ & $\checkmark$ & $x$ & $\checkmark$ & $\checkmark$ & $x$ & $x$ & $x$ \\
\hline Van Seventer et al. (2006) [25] & $\begin{array}{l}\text { France, Germany, Italy, } \\
\text { Netherlands, Spain, UK }\end{array}$ & $x$ & $x$ & $x$ & $\checkmark$ & $x$ & $\checkmark$ & $x$ & $x$ & $x$ & $\checkmark$ \\
\hline Volpi et al. (2007) [75] & Italy & $\checkmark$ & $x$ & $x$ & $x$ & $x$ & $x$ & $x$ & $x$ & $x$ & $\checkmark$ \\
\hline Volpi et al. (2008) [76] & Italy & $\checkmark$ & $\checkmark$ & $x$ & $\checkmark$ & $\checkmark$ & $x$ & $x$ & $x$ & $x$ & $\checkmark$ \\
\hline Weinke et al. (2010) [77] & Germany & $\checkmark$ & $x$ & $x$ & $\checkmark$ & $x$ & $x$ & $x$ & $\checkmark$ & $x$ & $\checkmark$ \\
\hline
\end{tabular}

$\checkmark$ and $\mathrm{x}$ indicate the presence/absence of evidence, respectively.

observational study of PHN patients over the age of 50 conducted in France, Germany, Italy, Netherlands, Spain and the UK $(n=84)$, for example, reported that neuropathic pain medications (89\%), analgesics (64\%) and anticonvulsants (52\%) were most commonly prescribed for the treatment of PHN [25]. However, a study conducted in the UK reported that antidepressants were most commonly prescribed for PHN followed by level 1 and 2 analgesics (59.2\%, 55.3\% and $50 \%$ respectively) [14]. Similarly, studies in Italy and Portugal have reported that anticonvulsants to be the most commonly prescribed treatment for PHN, followed by opioid analgesics $[29,44]$. Where reported, medication usage for the treatment of HZ was consistent across studies; with antivirals (typically taken for 7 days) the most commonly prescribed treatment $[14,21,29,42,50,71]$.

Of note, despite the widespread use of pharmacological therapies for the management of $\mathrm{HZ}$ and $\mathrm{PHN}$, reports from patients indicate dissatisfaction with treatments, particularly in regards to perceived efficacy $[14,50]$.

\section{Diagnostic/laboratory procedures}

Details of additional investigations among patients with $\mathrm{HZ}$ and PHN were reported from studies in France, Italy, Spain and the UK $[14,21,27,29,50]$. Additional investigations reported included blood and urine tests, assessments of inflammation (e.g. erythrocyte sedimentation rate, C-reactive protein level), ophthalmological/ ontological examinations, radiology, X-ray, electrocardiograms and ultrasound.
Further diagnostic or laboratory examinations were reported in $28.0 \%$ of incident cases of $\mathrm{HZ}$ among an Italian sample of immunocompetent individuals, with the mean number of procedures and examinations reported to be 2.6 per case [29]. By comparison, rates of additional investigations reported in France, Spain and the UK were lower $[14,21,27,50]$, with evidence suggesting that rates of additional investigations were higher in those with PHN (10-12.5\% compared to HZ (4.4-9\%) $[14,21,50]$. Additional investigations are also more likely among those patients with HZO compared to HZ [21].

\section{Direct costs of management}

Direct costs of the management of $\mathrm{HZ}$ and PHN patients were reported in 20 studies. The reviewed articles presented data from Spain $[27,37,45,51-53,69]$, the UK $[7,28,43,47,74]$, France [30], Italy [29,46], Germany [31,67], Belgium $[26,40]$, Greece [70] and Switzerland [72]. Outpatient costs (including medical visits, diagnostic tests and medications), hospitalization and inpatient costs were identified in the literature as key contributors to the overall cost burden of $\mathrm{HZ}$ and PHN.

\section{Outpatient costs}

Studies in Belgium [26], Germany [31,67], Italy [29] and the UK [28] have consistently reported higher outpatient management costs (including medical visits, diagnostic tests and medications) among patients who go on to develop PHN. For example, mean direct costs of outpatient management have been reported as $€ 107.98$ per $\mathrm{HZ}$ 
episode and $€ 406.04$ and $€ 485.51$ per PHN episode (1and 3 -month definition respectively) $[28]^{\mathrm{a}}$. In addition, costs for outpatient management of $\mathrm{HZ}$ and $\mathrm{PHN}$ have been reported to increase markedly with pain severity $[26,28]$. For example, outpatient costs among $\mathrm{HZ}$ patients ranging from $€ 85.89$ (no pain) to $€ 178.32$ (severe pain) per case have been reported in the UK. Reported differences are more pronounced among PHN patients with costs per case ranging from $€ 237.90 / 284.80$ (PHN1/PHN3) among patients with mild pain to $€ 741.91 / 878.88$ (PHN1/PHN3) among patients with severe pain [28] $]^{\mathrm{a}}$. Key differences in the attribution of outpatient costs for $\mathrm{HZ}$ and $\mathrm{PHN}$ have been reported for Italy; for patients that did not develop $\mathrm{PHN}$, the majority of the cost of management has been reported to be due to the cost of medication (83\%) whereas for patients that develop PHN a greater proportion of cost was attributed to diagnostic and investigative procedures [29]. Other studies, however, indicate costs of diagnostic procedures to be the smallest contributor to outpatient costs among patients with $\mathrm{HZ}$ and $\mathrm{PHN}$ (PHN-1 and PHN-3) [27].

While the average cost of outpatient management per case is higher for patients with PHN than for patients with HZ, when considering overall burden of disease at a country level, the overall cost of disease is higher for HZ. This is primarily a result of the higher incidence rates of $\mathrm{HZ}$. These differences were highlighted by one study which investigated the annual cost of $\mathrm{HZ}$ and PHN to healthcare providers located in England and Wales [47]. Based on an estimated 260,995 episodes of HZ occurring annually, with $14 \%$ of cases developing PHN, an estimated $€ 76.39$ million $^{\mathrm{a}}$ is spent on the management of HZ (including PHN). Of this, $€ 52.32$ million was attributable to $\mathrm{HZ}(€ 22.47 \mathrm{~m}$ due to hospitalisation, $€ 19.26 \mathrm{~m}$ due to prescription medications and $€ 9.63 \mathrm{~m}$ due to GP consultations) and $€ 24.07$ million to PHN1 (cost breakdown not provided). Similar findings are reported in Germany where statutory health insurance bills have been estimated at $€ 115.5 \mathrm{~m}$; €93.5 m attributed to $\mathrm{HZ}$ treatment and $€ 22 \mathrm{~m}$ attributed to treatment of PHN [31].

\section{Hospitalisation and inpatient costs}

Hospitalisation costs contribute significantly to the overall direct cost of managing $\mathrm{HZ}$ and PHN. Rates of hospitalisation and duration of stay were found to be higher for $\mathrm{PHN}$ than for $\mathrm{HZ}$, and to increase with increasing age, translating into higher inpatient costs for patients that develop PHN (Table 4) $[18,24,33,70]$. Note that data on hospitalisations and inpatient costs was primarily extracted from a range of national and insurance databases in each country. No studies identified provided a breakdown of the cost elements that are included in a 'hospital stay'.

\section{Indirect costs}

Indirect costs considered in the EU literature were mainly related to costs associated with sick leave (absenteeism). Seventeen articles reported data on sick leave due to $\mathrm{HZ}$ and $\mathrm{PHN}$ and the costs that this incurs $[7,26,27,29-31,40,42,58,60,63,69,70,72,73,77,82]$. Absenteeism due to $\mathrm{HZ}$ and $\mathrm{PHN}$ is a significant cost driver, with increased costs found to be associated with the presence of PHN [29,31,72] and increased levels of pain experienced [26,72]. Up to $65 \%$ of employed patients report work absence due to their disease [77].

Costs associated with absenteeism varied across EU countries. In France, these costs accounted for up to $30 \%$ of the costs of management of $\mathrm{HZ}$ from the societal perspective and up to $10 \%$ of the costs of management for PHN in patients aged 50 years and over [30]. In Germany, the mean annual cost of sick leave due to $\mathrm{HZ}$ was $€ 1,504$ per patient (increasing to $€ 1,826$ for patients over the age of 50), with patients missing an average of 12.5 days from work. The costs associated with PHN were found to be higher at $€ 7,183$ ( $€ 7.590$ for patients

Table 4 Mean cost per hospitalised case of HZ/PHN, by country

\begin{tabular}{llll}
\hline Country & HZ/PHN & HZ (without PHN) & PHN \\
\hline Belgium [40] & - & $€ 5,982(€ 798-31,689)$ & - \\
& & (all ages) & $€ 3,731.09$ (50+years) \\
France [41] & $€ 2,774.28$ (50+years) & $€ 4,279.68$ (50+years) \\
Germany [31] & $€ 4,189.74$ (50+years) & $€ 4,112.03$ (all ages) \\
& - & $€ 3,282.64$ (all ages) & $€ 3,451.38 \pm € 3,248.43$ (50+years) \\
Italy [29] & $€ 3,188.16 \pm € 1,614.99$ (50+years) & $€ 5,108.04$ (aged 50-59) \\
Spain [37,45,52,53] & $€ 5,019.84$ (aged 40-49) & $€ 4,732.56$ (aged 60-69) \\
& (all ages) & $€ 4,495.68-5,139.54$ (aged 50-59) & $€ 4,478.04$ (70+) \\
\hline
\end{tabular}


over 50) with patients missing an average of 2 months from work [31]. The average costs associated with absenteeism were found to be lower in Italy and Switzerland than those reported for Germany [29,72]. Average costs for patients over the age of 50 in Italy were $€ 684$ per case of $\mathrm{HZ}$ and $€ 978$ per case of $\mathrm{PHN}$ [29]. In Switzerland, reported costs of sick leave per case for patients with varying levels of pain were as follows: mild pain ( $\mathrm{HZ} € 335$; PHN 381), moderate pain (HZ €421; $\mathrm{PHN} € 1,018)$, severe pain $(H Z € 1,837 \text {; PHN } € 2,443)^{\mathrm{b}}$ [72].

In Spain, the findings from an observational study [27] of $130 \mathrm{HZ}$ patients aged 19-45 (median age of $63.5 \mathrm{yrs)}$ who were observed for 1 year suggest that an average of 4.3 hours of work were missed per patient at a cost of $€ 52.98$. This study also found that a total of 6 work hours were lost by carers across the study sample of 130 , resulting in a total loss of $€ 86.31$. The cost and time implications of time taken off work by carers were also considered in two further studies that were conducted in Belgium and the UK respectively. The study conducted in Belgium found that 14/184 patients reported that someone else could not go to work due to their illness for between 0.5-10days, resulting in an average loss of $€ 52$ per case due to carer absenteeism [40]. For the study conducted in the UK, among $70 \mathrm{HZ}$ patients, a total of 52 work days were lost by their carers [7]. However as the majority of the reviewed studies usually do not report the cost burden associated with time lost by carers this cost is likely to be underestimated.

\section{Total costs of management}

A total of 10 studies reported the total cost per case of $\mathrm{HZ}$ and/or PHN in EU countries, taking into account both direct costs (including medical visits, medications and hospitalisations) and indirect costs (including time missed from work). Table 5 presents the average cost per case in each country based on the data that was detailed in the reviewed literature. Overall, higher costs were consistently associated with the presence of PHN and increased levels of pain. Of note, whilst $\mathrm{HZ}$ and PHN are associated with higher costs to healthcare providers in elderly populations, costs to society in terms of time missed for work tends to be lower, so the total costs overall are similar across age groups [60].

The total annual cost (direct and indirect costs) of $\mathrm{HZ}$ and PHN on a country level basis was only available for the UK [43], France [30], Germany [31], Italy [29] and Sweden [63]. Two studies presented data separately for the cost of $\mathrm{HZ}$ and PHN and patients over the age of 50 $[29,31]$. Further details are provided in Figure 2.

\section{Humanistic burden and impact on quality of life}

A total of 21 EU studies [7,14,15,21,25,28,42,44,48,50,56-58, $62,65,66,68,75-77]$ reported data on the humanistic burden associated with $\mathrm{HZ}$ and $\mathrm{PHN}$, with the significant negative impact of $\mathrm{HZ}$ and $\mathrm{PHN}$ on patients' HRQOL consistently reported. Of note, pain experienced due to the disease was found to interfere with many aspects of patient's daily life. Greater interference was associated with increased levels of

Table 5 Mean total cost of management per $\mathrm{HZ}$ or PHN case

\begin{tabular}{|c|c|c|c|c|}
\hline \multirow[t]{2}{*}{ Country } & \multirow{2}{*}{$\begin{array}{l}\text { Population } \\
\text { age }\end{array}$} & \multicolumn{3}{|l|}{ Cost per case } \\
\hline & & $\mathrm{HZ}$ & PHN1* & PHN3^ \\
\hline \multirow[t]{2}{*}{ Belgium [26] } & Aged $\geq 50$ & $€ 118$ (no pain) & $€ 156.94$ (mild pain) & $€ 329.22$ (mild pain) \\
\hline & & $€ 1,150.50$ (severe pain) & $€ 1,085.60$ (severe pain) & $€ 2,037.86$ (severe pain) \\
\hline France [30] & Aged $\geq 50$ & $€ 419.87(271-586)$ & $€ 672.76$ (451-968) & - \\
\hline Germany [31] & Aged $\geq 50$ & $€ 388.30(354-425)$ & - & $€ 1,427.80(1,002-1,917)$ \\
\hline Germany [67] & Aged $\geq 50$ & $€ 729.57$ & $€ 2,167.89$ & \\
\hline Italy [29] & Aged $\geq 50$ & $€ 888.06$ & - & $€ 1,66.65$ \\
\hline \multirow[t]{4}{*}{ Spain [27] } & Aged $>14$ & Overall: €446.04 (SD 508.58) & $€ 647.82$ (SD 684.4) & $€ 968.78$ (SD 803.58) \\
\hline & & 50-59: €282.06 (SD 273.15) & & \\
\hline & & 60-69:€510.52 (SD 512.73) & & \\
\hline & & >70: €422.91 (SD 388.66) & & \\
\hline Spain [69] & Aged $>30$ & $€ 460.95$ & $€ 1,956.15$ & - \\
\hline Sweden [63] & All ages & & $€ 902.88(\mathrm{HZ}$ and PHN) & \\
\hline \multirow[t]{2}{*}{ Switzerland [72] } & Aged $\geq 50$ & $€ 394.46$ (no pain) & - & $€ 381.15$ (no pain) \\
\hline & & $€ 1,835.57$ (severe pain) & & $€ 2,442.99$ (severe pain) \\
\hline \multirow[t]{2}{*}{ UK [7] } & Not specified & $€ 793.60(31-6,394)$ & - & - \\
\hline & (all ages) & Aged +65: $€ 788.48$ & & \\
\hline
\end{tabular}




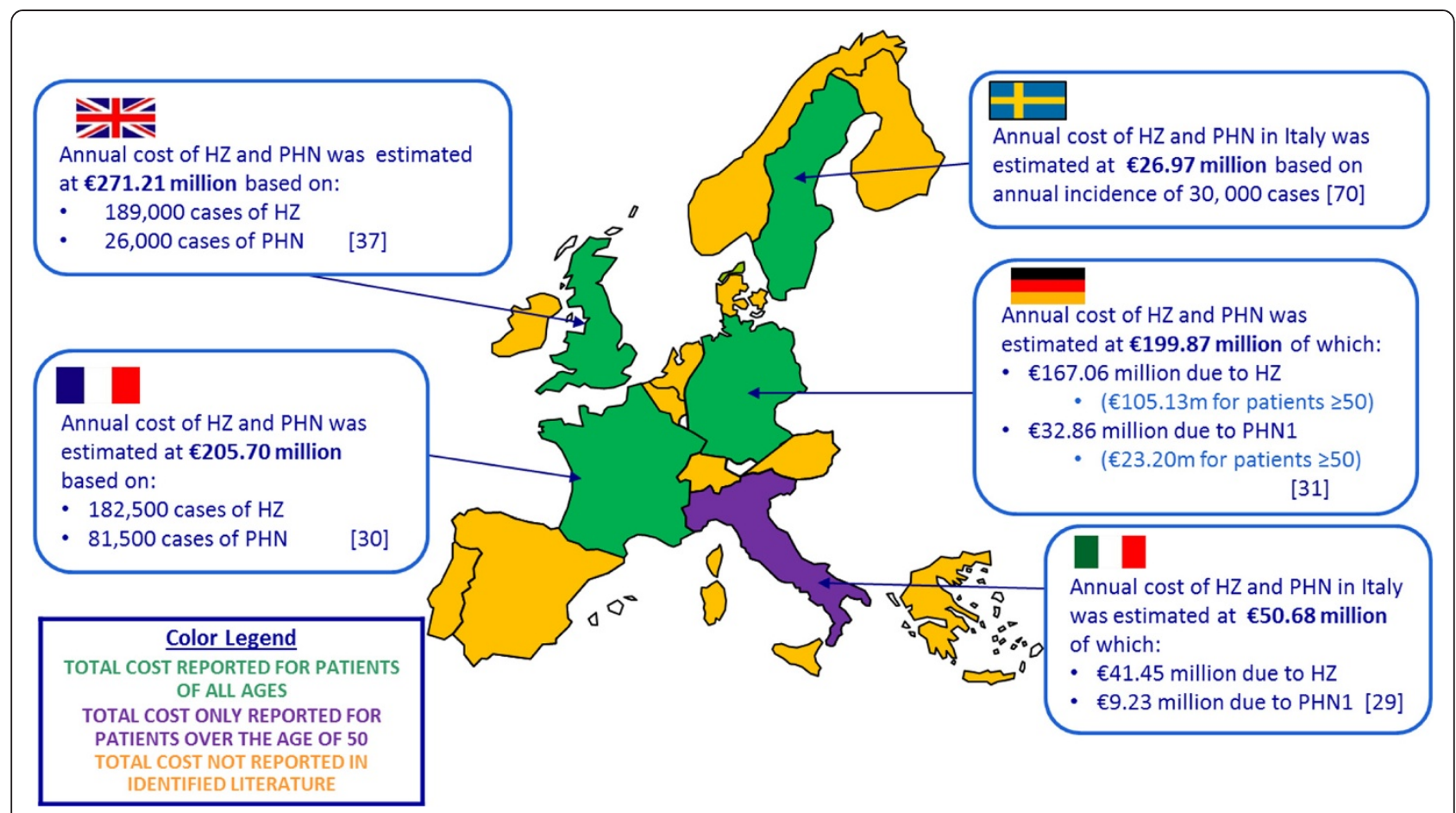

Figure 2 Estimated total cost burden associated with $\mathrm{HZ}$ and PHN considering outpatient, hospitalisation and indirect costs.

pain $[25,83]$ and the presence of PHN was associated with a greater impact on most domains of HRQoL [14,50,58,77]. Patients also reported consequences for their family and social circle when suffering from HZ or PHN $[58,77,84]$.

\section{Pain and interference with daily activities}

Reports within the reviewed literature indicate that patients with $\mathrm{HZ}$ and $\mathrm{PHN}$ experience moderate-severe pain. Ratings of average and worst pain reported in the literature are higher among PHN patients compared to HZ patients [14,41,50,58,77].

A number of the reviewed articles provided data from the Zoster Brief Pain Inventory (ZBPI) and the Modified Brief Pain Short Form (mBPI-SF) ${ }^{\mathrm{C}}$ - derivative measures of the Brief Pain Inventory (BPI) which require patients to rate the level of interference they experience on a scale of $0-10$ ('does not interfere' - 'completely interferes'), across seven health status domain; general activity, mood, walking ability, normal work, social relations, sleep and enjoyment of life. Table 6 presents the mean scores for patients with $\mathrm{HZ}$ and PHN from five studies. In general, reports of pain interference on all seven health status domains were greater among patients experiencing PHN compared to patients with HZ [14,50,58,77]. $\mathrm{HZ}$ and PHN patients reported sleep to be the aspect of their daily lives most affected by pain (4.5-4.9 and 6.3-6.5 mean scores respectively), while walking ability was the least affected in HZ patients (1.7-4.0 mean score) and enjoyment of life was least affected in PHN patients (3.8-5.2 mean score) $[14,15,50,58,77]$. Increased levels of pain are reported to be associated with increased levels of interference $[25,83]$. Levels of pain interference, however, do not appear to be associated with age. Lukas et al. [58] presented pain interference data separately for six European countries included in the study. While differences in the level of interference observed varied from country to country, the domains of health status most affected was largely consistent.

\section{Impact on general health-related quality of life}

A number of studies have included generic HRQoL measures such as the SF-12 [15,83], SF-36 [14,21,50], EQ-5D $[7,14,25,50]$ and Short Italian Questionnaire (SIQ) $[75,76]$

Table 6 Level of pain interference across seven health state domains as assessed by the ZBPI (or similar instrument)

\begin{tabular}{lll}
\hline Health state domains & HZ (mean scores) & PHN (mean scores) \\
\hline General activity & $3.8-4.4$ & $3.1-5.7$ \\
Mood & $3.4-4.5$ & $3.4-5.9$ \\
Walking ability & $1.7-4.0$ & $1.7-5.8$ \\
Normal work & $3.3-4.4$ & $2.9-6.1$ \\
Social relations & $2.1-3.5$ & $2.1-5.4$ \\
Sleep & $4.5-4.9$ & $6.3-6.5$ \\
Enjoyment of life & $3.6-4.0$ & $3.8-5.2$ \\
\hline
\end{tabular}

Data from Bouhassira 2012 [15], Gater 2014 [50], Lukas 2012 [58], Serpell 2014 [14], Weinke 2010 [77]. 
to assess HRQoL in HZ and PHN patients. Generally, HRQoL has found to be inversely associated with levels of reported pain $[14,25,50,83]$ and the poorest HRQoL has been observed for patients with PHN [14,21,50].

Consideration of HRQoL scores from normative populations indicates an inverse relationship between age and HRQoL. As a condition mainly inflicting the elderly, therefore, HRQoL is already considerably compromised in $\mathrm{HZ}$ and PHN patients. Nonetheless, recent research indicates that both $\mathrm{HZ}$ and PHN patients demonstrate statistically significant and clinically relevant deficits in HRQoL when scores for validated measures of HRQoL (e.g. SF-36 and EQ-5D) among these populations are compared to those from aged-matched normative samples (Figures 3 and 4) [14,50].

\section{Impact on mood and mental well-being}

Data presented across studies demonstrates that patients experience a negative impact on their mood and mental well-being, with patients reporting stress, anxiety and depressive symptoms [14,15,50,56,58,76,77]. Across studies, a range of instruments have been used to assess the impact of $\mathrm{HZ}$ and PHN on mood, including the Hospital Anxiety and Depression scale (HADS) [7,15], 10,47 Short Italian Questionnaire (SIQ) [75,76], the Short Anxiety Screening Test (SAST) [56] and bespoke questions [58,77]. Up to $29 \%$ of patients with $\mathrm{HZ}$ reported feelings of moderate anxiety or depression, rising to $43 \%$ in patients with PHN. Further, a larger percentage of PHN patients reported extreme anxiety or depression ( $11 \%$ vs. $5 \%$ ) [58,77], evidencing that mood and mental well-being issues are greater for PHN patients. The majority of patients reported experiencing stress some of the time (up to $78 \%$ for $\mathrm{HZ}$ and $91 \%$ for PHN) or most of the time (up to $19 \% \mathrm{HZ}$ and $41 \%$ PHN) [58,77].

\section{Impact on family and social relations}

Up to $50 \%$ of patients with $\mathrm{HZ}$ and $81 \%$ of patients with PHN reported consequences for their family members and social circle [58,77]. Despite the high proportion of patients reporting impacts on their social and family lives, only three studies assessed this issue beyond comparing scores on social dimensions of instruments such as the ZBPI or SF-36 $[58,77,84]$. In one study in particular, one fifth of the respondents felt isolated from their family and friends while suffering from $\mathrm{HZ}$ or PHN, with $19 \%$ and $27 \%$ of patients respectively reporting reduced communication during their illness [58]. Of note, impacts were not limited to the patient themselves, with findings from a qualitative focus group of patient's relatives demonstrating that relatives were worried and stressed by the impact of $\mathrm{HZ}$ on the patients [84].

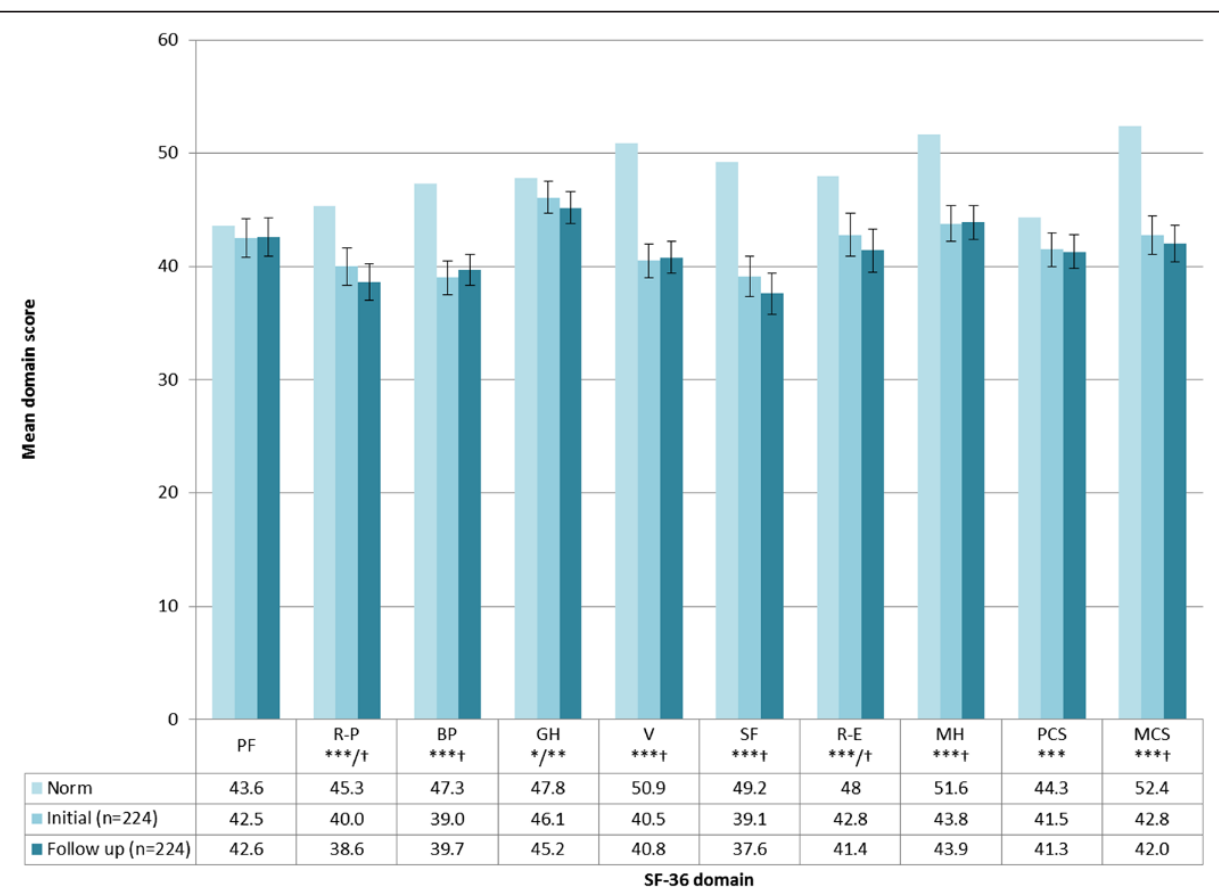

Figure 3 Comparison of SF-36 domain and component scores for HZ patients compared to age-matched norms [50]. No ${ }^{*} p \geq 0.05,{ }^{*} p<0.05$; ${ }^{* *} p>0.01 ;{ }^{* * *} p<0.001 . t=$ clinically meaningful PF=Physical functioning, $R-P=$ Role-physical, $B P=$ Bodily pain, GH=General health, $V=V i t a l i t y, S F=S o c i a l$ functioning, $R$-E=Role-emotional, $M H=$ Mental health, $P C S=P h y s i c a l$ component summary, MCS=Mental component summary. Note: Data collected on initial presentation of $\mathrm{HZ}$ to healthcare professional and then again 7-14 days later (follow-up). 


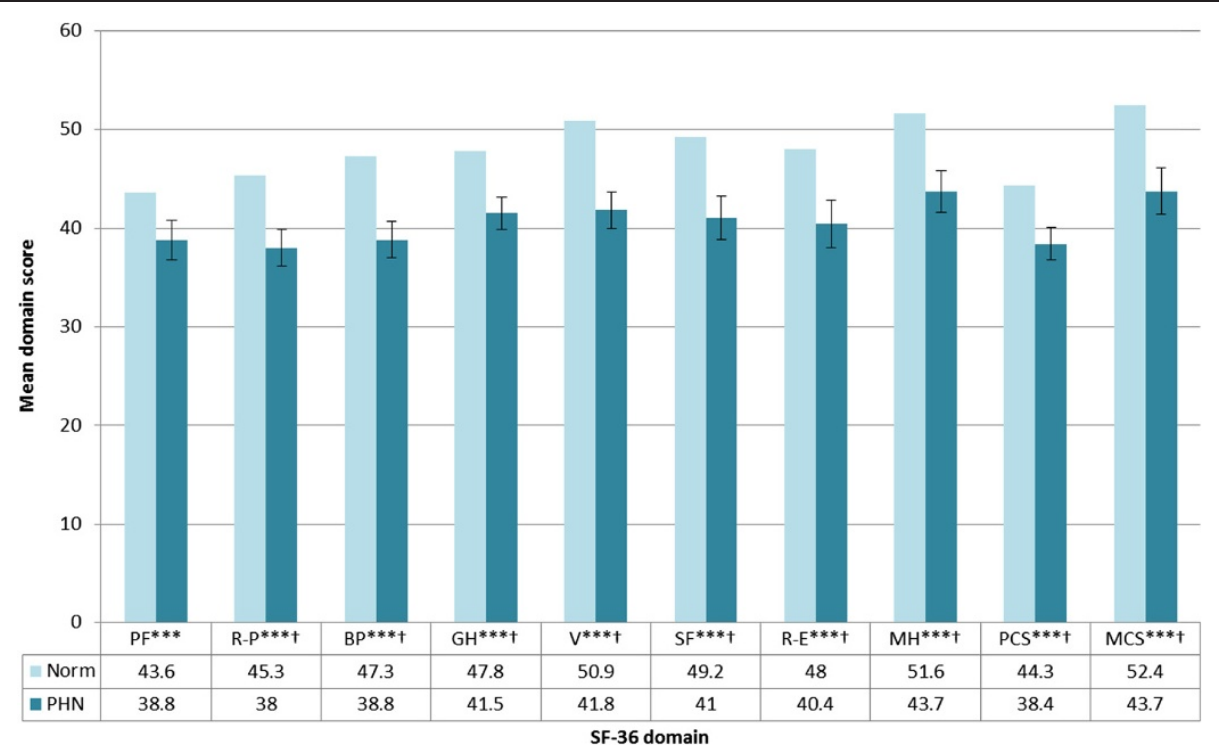

Figure 4 Comparison of SF-36 domain and component scores for PHN patients compared to age-matched norms [14]. No ${ }^{*} p \geq 0.05$, ${ }^{*} p<0.05 ;{ }^{* *} p<0.01 ;{ }^{* *} p<0.001 .+=$ clinically meaningful $P F=P$ hysical functioning, $R-P=$ Role-physical, $B P=B$ odily pain, GH=General health, $V=V i t a l i t y, S F=S o c i a l$ functioning, $R$-E=Role-emotional, MH=Mental health, PCS=Physical component summary, MCS=Mental component summary.

\section{Discussion}

The aim of this article was to provide a holistic overview of the published literature concerning the humanistic, economic and societal burden of $\mathrm{HZ}$ and PHN in Europe. The reviewed evidence highlights the significant burden of $\mathrm{HZ}$ and PHN for patients, healthcare systems and wider society. A number of key findings are noted. Firstly, the direct costs of managing HZ represent a significant proportion of the total costs associated with the disease, with higher costs associated with the presence of PHN and with greater pain severity. Secondly, absenteeism was identified as a significant cost driver (albeit in a small number of studies), with up to $65 \%$ of employed patients reporting work absence due to their disease. Lastly, research suggests that age, pain severity and the presence of PHN are the key drivers of burden to patients, healthcare systems and society.

In Europe the percentage of people aged 65 years or over is projected to increase from $17.1 \%$ (84.6million) in 2008 to $30.0 \%$ ( 151.5 million) in 2060 [85]. This demographic shift is likely to have a profound influence on the incidence of $\mathrm{HZ}$ and PHN and may contribute to increased concern among European healthcare authorities; particularly if economic crisis and healthcare budget constrains persist in the long term. Findings from this review indicate that the direct costs of $\mathrm{HZ}$ and $\mathrm{PHN}$ management are greater for older patients. In addition, older adults typically have lower HRQoL than younger adults (deficits which are more pronounced with the presence of $\mathrm{HZ}$ and $\mathrm{PHN}$ ) and may be less able to complete activities of daily living and self-care unassisted.
The potential implications of an aging population to wider society, therefore, are wide reaching.

\section{Limitations of the current literature and potential gaps} that provide opportunities for future research

A number of limitations concerning the currently available body of evidence were identified.

\section{Inconsistencies in data}

There is currently no consensus regarding the definition of PHN and a lack of consistency in the definition of PHN employed in studies was evident throughout the review. This presents a number of challenges when attempting to accurately understand the burden of $\mathrm{HZ}$ and PHN. For example, it has been demonstrated that the prevalence of PHN varies dramatically depending on the point at which HZ-related pain becomes classified as PHN (PHN1 or PHN3) [86]. Accurately attributing costs to $\mathrm{HZ}$ and PHN and determining the overall cost burden of the conditions, therefore, is difficult. Similarly, cost per case may vary dramatically depending on the definition employed. For this reason, PHN definitions employed in the referenced studies have been highlighted throughout this review and should be considered when interpreting the findings from individual studies.

Furthermore, there is a lack of consistency in the use of International Classification of Diseases (ICD) codes used to identify PHN patients in clinical practice. As a result, there may be a significant proportion of PHN patients who have not been considered in these studies; 
consequently decreasing confidence in the accuracy of estimates regarding the burden of PHN.

A lack of consistency in the ways in which data had been collected provides further difficulties in interpreting and comparing the available data across studies, with databases, patient records and patient surveys all utilized. For example, rates of resource use were derived from a range of sources including: analysis of patient records or an observed sample, patient responses to surveys and national and insurance databases, with each of these methods having their own limitations. The use of databases is a valuable way of gathering data at a national level, however it assumes information is recorded consistently and accurately across databases and that the database has adequate and representative population coverage. Analysis of patient records assumes information is accurately recorded by GPs, who have a myriad of demands on their time, and analysis of patient's responses assumes accuracy in their recall. Of note, the incidence of hospitalisations were largely based on rates derived from databases in different countries, or rates recorded in observed samples, thus inaccuracies may occur when these data are extrapolated to the country population. Variation in reports of healthcare resource use, indirect costs and humanistic burden are also likely to have resulted from inconsistency in the time frame that different studies considered relevant.

With respect to the literature on economic burden, it is understood that costs are likely to vary between countries in terms of the cost of medical resources, medical visits and prescribed medications. Currently these differences are not reflected in the published literature and in some cases, the cost of treating a case of $\mathrm{HZ}$ or PHN were calculated inconsistently, with some studies presenting the cost per treated case while others presented the average across all patients. As such there was a wide variation between studies. Only one study provided costs (per treated case) for the different types of medications used to treat HZ or PHN [46]. Similarly, no studies provided breakdown or clarification of cost elements included in a 'hospital stay'. Great caution, therefore, should be taken in comparing and interpreting the available data. Furthermore this highlights an unmet need for data that clearly distinguishes between $\mathrm{HZ}$ and PHN and also for 'per treated case' data for a wide range of EU countries.

A further notable limitation was that data were not available for all EU countries. Despite comprehensive database searches, in which no restrictions on country of interest or language of publication were implemented, cost burden data for the majority of Eastern European countries was not identified. The majority of studies, instead, focus primarily on the UK, Spain, France, Italy, Belgium and Germany.

\section{Gaps in evidence}

A number of evidence gaps were identified, some of which provide opportunities for future research. A key gap identified in the available evidence pool relates to how indirect costs are assessed. While a number of EU studies presented data on the time missed from work and associated costs, data on productivity while at work and associated costs is lacking. Studies in the US and Canada, however, report that presenteeism could account for up to $75 \%$ of the cost burden associated with work loss [87] and that an average of 46 hours were lost (per employed patient) due to presenteeism [88].

In Europe, decisions regarding access and reimbursement of medical interventions are predominately driven by considerations of cost-effectiveness. Consideration of the impact of conditions as reported by patients themselves, however, provides important information regarding unmet need and the efficacy of medical interventions. A number of studies assessing aspects of humanistic burden associated with $\mathrm{HZ}$ and PHN were identified. However, there are number of notable limitations. Firstly, the impact of $\mathrm{HZ}$ and PHN was generally assessed using disease specific questionnaires (such as the ZBPI) or 'bespoke' questions which have not been tested or validated. There was only limited use of generic HRQoL instruments in the EU studies conducted to date. However, data from such instruments are valuable for quantifying burden with reference to the normative population and patients with other diseases - data that is important for contextualizing the relative burden associated with $\mathrm{HZ}$ and PHN. The available evidence does not typically look beyond the pain which accompanies or persists beyond the rash and the omission of other factors that can impact on patients' quality of life (e.g. fatigue, stomach upsets, allodynia, and numbness). This should be addressed, preferably through a combination of quantitative and qualitative research, the latter of which was notably lacking in the literature.

Finally, the lack of literature relating to the wider societal burden potentially caused by HZ and PHN (particularly with respect to the impact on caregivers and the broader implications of $\mathrm{HZ}$ and $\mathrm{PHN}$ on provision of formal and informal social care) may be considered a critical gap. To date burden among informal caregivers has rarely been considered, and only in terms of time lost from work. Significantly, this omits the potential impacts of providing informal care to patients that may not have resulted in time lost from work (e.g. negative impact on the health and well-being of caregivers). Furthermore, consideration of healthcare resource use and the economic burden of $\mathrm{HZ}$ and PHN has typically focussed on impacts within the healthcare system; the broader implications of $\mathrm{HZ}$ and $\mathrm{PHN}$ are rarely appreciated. For example, the functional deficits observed among $\mathrm{HZ}$ and PHN patients that may lead to a loss of autonomy and 
increased reliance on formal paid care have not been estimated. Beyond some evidence of direct and indirect costs related to the disease, the potential impact of $\mathrm{HZ}$ and PHN on the social care system remains unknown.

\section{Conclusions}

This literature review highlights the burden faced by patients, healthcare systems and society due to $\mathrm{HZ}$ and PHN in Europe. While the incidence of HZ and PHN increases with age, the total cost per case of $\mathrm{HZ}$ and $\mathrm{PHN}$ management is not necessarily age-dependent. Pain severity was associated with increased costs for both $\mathrm{HZ}$ and PHN, and, as a chronic condition, costs were higher for patients experiencing PHN. No study fully addressed the humanistic and economic burden of $\mathrm{HZ}$ and PHN to patients, their families and society as a whole. Based on the reviewed evidence and an assessment of the gaps in the evidence base, it is likely that the true burden of $\mathrm{HZ}$ and PHN is underestimated in the Europe. Further research is required to build a holistic understanding of the impact of $\mathrm{HZ}$ and PHN to patients, healthcare systems and society.

\section{Endnotes}

${ }^{\mathrm{a} *}$ Costs originally reported in 2006 GBP sterling $(£)$, converted to euros $(€)$ using the following conversion rate $£ 1=€ 1.18$.

${ }^{\mathrm{b} *}$ Costs originally reported in 2006 Swiss francs (CHF), converted to euros $(€)$ using the following conversion rate $1 \mathrm{CHF}=€ 0.81$.

${ }^{\mathrm{c}}$ Although 2 studies do not report a specific instrument, items reported appear to be derived from the ZBPI $(38,55)$.

\section{Competing interests}

AG and RM are/were employees of Adelphi Values, a health outcomes agency commissioned by Sanofi Pasteur MSD, to conduct, analyse and communicate findings from this research on their behalf. $M U$ and EP are employees of Sanofi Pasteur MSD, a provider of a herpes zoster vaccine approved in the European Union. The authors have no other competing interests to declare.

\section{Authors' contributions}

$A G$ and EP designed the study. RA and AG conducted the literature searches, determined eligibility of studies for inclusion in the review and were responsible for primary data extraction and analysis. EP and MU contributed to the analysis. AG, EP and MU drafted the manuscript. All authors read and approved the final manuscript.

\section{Acknowledgements}

The authors would like to thank Florence Baron-Papillon and Nathalie Largeron, employees of Sanofi Pasteur MSD (Lyon, France), for their support in the preliminary searches and their critical review. They would also like to thank Jessica Costello (Adelphi Values) for assistance in data extraction of non-English articles included in this review, and Sophi Tatlock and Adam Moore (Adelphi Values) for editorial support during the development of the manuscript.

\section{Author details}

${ }^{1}$ Adelphi Values, Adelphi Mill, Grimshaw Lane, Bollington, Cheshire SK10 5JB, UK. Sanofi Pasteur MSD, 162 avenue Jean Jaurès, Lyon, France.
Received: 1 September 2014 Accepted: 9 February 2015

Published online: 27 February 2015

\section{References}

1. Opstelten W, Eekhof J, Neven AK, Verheij T. Treatment of herpes zoster. Can Fam Phys Med Fam Can. 2008;54(3):373-7.

2. Sengupta N, Booy R, Schmitt HJ, Peltola H, Van-Damme P, Schumacher RF, et al. Varicella vaccination in Europe: are we ready for a universal childhood programme? Eur J Pediatr. 2008;167(1):47-55.

3. Pinchinat S, Cebrián-Cuenca AM, Bricout H, Johnson RW. Similar herpes zoster incidence across Europe: results from a systematic literature review. BMC Infect Dis. 2013;13(1):1-10.

4. Schmader K, Gnann Jr JW, Watson CP. The epidemiological, clinical, and pathological rationale for the herpes zoster vaccine. J Infect Dis. 2008;197 Suppl 2:S207-15.

5. Lancaster T, Silagy C, Gray S. Primary care management of acute herpes zoster: systematic review of evidence from randomized controlled trials. $\mathrm{Br}$ J Gen Pract. 1995;45(390):39-45.

6. Dworkin $\mathrm{R}$, Schmander $\mathrm{K}$. The epidemiology and natural history of herpes zoster and postherpetic neuralgia. 2nd ed. Amsterdam: Elsevier; 2001.

7. Scott FT, Johnson RW, Leedham-Green M, Davies E, Edmunds WJ, Breuer J. The burden of Herpes Zoster: a prospective population based study. Vaccine. 2006;24(9):1308-14.

8. Johnson RW, Rice AS. Pain following herpes zoster: the influence of changing population characteristics and medical developments. Pain. 2007;128(1-2):3-5.

9. Johnson RW, Wasner G, Saddier P, Baron R. Postherpetic neuralgia: epidemiology, pathophysiology and management. Expert Rev Neurother. 2007;7(11):1581-95.

10. Bowsher D. The management of postherpetic neuralgia. Postgrad Med J. 1997;73(864):623-9.

11. Oxman MN, Levin MJ, Johnson GR, Schmader KE, Straus SE, Gelb LD, et al. A vaccine to prevent herpes zoster and postherpetic neuralgia in older adults. N Engl J Med. 2005;352(22):2271-84.

12. Helgason S, Petursson G, Gudmundsson S, Sigurdsson JA. Prevalence of postherpetic neuralgia after a first episode of herpes zoster: prospective study with long term follow up. BMJ. 2000;321(7264):794-6.

13. Kost RG, Straus SE. Postherpetic neuralgia-pathogenesis, treatment, and prevention. N Engl J Med. 1996;335(1):32-42.

14. Serpell M, Gater A, Carroll S, Abetz-Webb L, Mannan A, Johnson R. Burden of post-herpetic neuralgia in a sample of UK residents aged 50 years or older: Findings from the zoster quality of life (ZQOL) study. Health Qual Life Outcomes. 2014;12(1):92.

15. Bouhassira D, Chassany O, Gaillat J, Hanslik T, Launay O, Mann C, et al. Patient perspective on herpes zoster and its complications: an observational prospective study in patients aged over 50 years in general practice. Pain. 2012;153(2):342-9.

16. Choo PW, Galil K, Donahue JG, Walker AM, Spiegelman D, Platt R. Risk factors for postherpetic neuralgia. Arch Intern Med. 1997;157(11):1217-24.

17. Coen PG, Scott F, Leedham-Green M, Nia T, Jamil A, Johnson RW, et al. Predicting and preventing post-herpetic neuralgia: are current risk factors useful in clinical practice? Eur J Pain. 2006;10(8):695-700.

18. Opstelten W, Mauritz JW, de Wit NJ, van Wijck AJ, Stalman WA, van Essen GA. Herpes zoster and postherpetic neuralgia: incidence and risk indicators using a general practice research database. Fam Pract. 2002;19(5):471-5.

19. Opstelten W, Zuithoff NP, van Essen GA, van Loon AM, van Wijck AJ, Kalkman CJ, et al. Predicting postherpetic neuralgia in elderly primary care patients with herpes zoster: prospective prognostic study. Pain. 2007;132 Suppl 1:S52-9.

20. Schmader KE, Sloane R, Pieper C, Coplan PM, Nikas A, Saddier P, et al. The impact of acute herpes zoster pain and discomfort on functional status and quality of life in older adults. Clin J Pain. 2007;23(6):490-6.

21. Chidiac C, Bruxelle J, Daures JP, Hoang-Xuan T, Morel P, Leplege A, et al. Characteristics of patients with herpes zoster on presentation to practitioners in France. Clin Infect Dis: Offic Publ Infect Dis Soc Am. 2001;33(1):62-9.

22. Drolet $M$, Brisson $M$, Schmader KE, Levin MJ, Johnson R, Oxman MN, et al. The impact of herpes zoster and postherpetic neuralgia on health-related quality of life: a prospective study. CMAJ: Can Med Assoc J = J Assoc Med Can. 2010;182(16):1731-6. 
23. Katz J, Cooper EM, Walther RR, Sweeney EW, Dworkin RH. Acute pain in herpes zoster and its impact on health-related quality of life. Clin Infect Dis: Offic Publ Infect Dis Soc Am. 2004;39(3):342-8.

24. Oster G, Harding G, Dukes E, Edelsberg J, Cleary PD. Pain, medication use, and health-related quality of life in older persons with postherpetic neuralgia: results from a population-based survey. J Pain. 2005;6(6):356-63.

25. van Seventer R, Sadosky A, Lucero M, Dukes E. A cross-sectional survey of health state impairment and treatment patterns in patients with postherpetic neuralgia. Age Ageing. 2006;35(2):132-7.

26. Annemans L, Bresse X, Gobbo C, Papageorgiou M. Health economic evaluation of a vaccine for the prevention of herpes zoster (shingles) and post-herpetic neuralgia in adults in Belgium. J Med Econ. 2010;13(3):537-51.

27. Cebrián-Cuenca A, Díez-Domingo J, San-Martín-Rodríguez M, Puig-Barberá J, Navarro-Pérez J. Epidemiology and cost of herpes zoster and postherpetic neuralgia among patients treated in primary care centres in the Valencian Community of Spain. BMC Infect Dis. 2011;11(1):302.

28. Gauthier A, Breuer J, Carrington D, Martin M, Remy V. Epidemiology and cost of herpes zoster and post-herpetic neuralgia in the United Kingdom. Epidemiol Infect. 2009;137(1):38-47.

29. Gialloreti LE, Merito M, Pezzotti P, Naldi L, Gatti A, Beillat M, et al. Epidemiology and economic burden of herpes zoster and post-herpetic neuralgia in Italy: a retrospective, population-based study. BMC Infect Dis. 2010;10:230.

30. Mick G, Gallais JL, Simon F, Pinchinat S, Bloch K, Beillat M, et al. [Burden of herpes zoster and postherpetic neuralgia: Incidence, proportion, and associated costs in the French population aged 50 or over]. Rev Epidemiol Sante Publique. 2010;58(6):393-401.

31. Ultsch B, Koster I, Reinhold T, Siedler A, Krause G, Icks A, et al. Epidemiology and cost of herpes zoster and postherpetic neuralgia in Germany. Eur J Health Econ: HEPAC: Health Econ Prev Care. 2012;14(6):1015-26.

32. Rothberg MB, Virapongse A, Smith KJ. Cost-effectiveness of a vaccine to prevent herpes zoster and postherpetic neuralgia in older adults. Clin Infect Dis: Offic Publ Infect Dis Soc Am. 2007:44(10):1280-8.

33. Schmader KE, Levin MJ, Gnann Jr JW, McNeil SA, Vesikari T, Betts RF, et al. Efficacy, safety, and tolerability of herpes zoster vaccine in persons aged 50-59 years. Clin Infect Dis. 2012;54(7):922-8.

34. Collaboration TC: Cochrane Handbook for Systematic Reviews of Interventions Version 5.1.0 [updated March 2011]: Available from www.cochrane-handbook.org; 2011.

35. Higgins JPT GS. Cochrane Handbook for Systematic Reviews of Interventions Version 5.1.0 [updated March 2011], The Cochrane Collaboration. 2011.

36. Eurostat. Harmonised Index of Consumer Prices. 2014.

37. Bayas J, Gil R, Llupiá A, Díez C, Conesa A, Ariza C, et al. Hospitalizaciones por herpes zoster y neuralgia postherpética en Cataluña, 1998-2003. Vacunas. 2011;12(4):122-8.

38. Berrut G, Baptiste C. Ophthalmic herpes zoster, a complication with a poor prognosis, is now a vaccine-preventable disease. Eur Geriatr Med. 2013;4:S116.

39. Blein C, Gavazzi G, Paccalin M, Baptiste C, Vainchtock A. Evaluation of the herpes zoster impact as comorbidity factor in 5 pathologies French hospital care among adults aged 50 and older. Value Health: J Int Soc Pharmacoeconomics Outcomes Res. 2013;16(7):A503.

40. Bilcke J, Ogunjimi B, Marais C, de Smet F, Callens M, Callaert K, et al. The health and economic burden of chickenpox and herpes zoster in Belgium. Epidemiol Infect. 2012;140(11):2096-109.

41. Bresse X, Annemans L, Preaud E, Bloch K, Duru G, Gauthier A. Vaccination against herpes zoster and postherpetic neuralgia in France: a cost-effectiveness analysis. Expert Rev Pharmacoeconomics Outcomes Res. 2013;13(3):393-406.

42. Bricout $H$, Perinetti E, Marchettini P, Ragni P, Zotti C, Gabutti G, et al. Description of herpes zoster patients aged over 50 years in Italy-A GP based multi center prospective observational study. Eur Geriatr Med. 2013;4:S116-7.

43. Brisson M, Edmunds WJ. Varicella vaccination in England and Wales: cost-utility analysis. Arch Dis Child. 2003;88(10):862-9.

44. Castro-Lopes JM, Menezes J, Mendonca L, Costa-Pereira A, Azevedo L. The impact of post-herpetic neuralgia: a prospective multicentre study on pain and health related quality of life. Eur Geriatr Med. 2013;4:S79.

45. de Juanes J, Arrazola P, García de Codes A, Ariza C, Gil R, San Martín M, et al. Hospitalizaciones por herpes zoster y neuralgia postherpética en la Comunidad de Madrid, 1998-2003. Vacunas. 2011;12(4):129-35.

46. Di Legami V, Gianino MM, Ciofi degli Atti M, Massari M, Migliardi A, Tomba GS, et al. Epidemiology and costs of herpes zoster: background data to estimate the impact of vaccination. Vaccine. 2007;25(43):7598-604.
47. Edmunds WJ, Brisson M, Rose JD. The epidemiology of herpes zoster and potential cost-effectiveness of vaccination in England and Wales. Vaccine. 2001;19(23-24):3076-90.

48. Franco E, Perinetti E, Marchettini P, Ragni P, Zotti C, Gabutti G, et al, Proportion of post herpetic neuralgia among patients with herpes zoster in Italy-A multicenter prospective observational study. Eur Geriatr Med. 2013;4:S115-6.

49. García-Doval I, Pérez-Zafrilla B, Descalzo MÁ, Roselló R, Hernández MV, Gómez-Reino JJ, et al. Incidence and risk of hospitalisation due to shingles and chickenpox in patients with rheumatic diseases treated with TNF antagonists. Ann Rheum Dis. 2010;69(10):1751-5.

50. Gater A, Abetz-Webb L, Carroll S, Mannan A, Serpell M, Johnson R. Burden of herpes zoster in the UK: findings from the zoster quality of life (ZQOL) study. BMC Infect Dis. 2014;14(1):402.

51. Gil A, San-Martin M, Carrasco P, Gonzalez A. Epidemiology of severe varicella-zoster virus infection in Spain. Vaccine. 2004;22(29-30):3947-51.

52. Gil A, Gil R, Alvaro A, San Martin M, Gonzalez A. Burden of herpes zoster requiring hospitalization in Spain during a seven-year period (1998-2004). BMC Infect Dis. 2009;9:55

53. Gil-Prieto R, San-Martín M, Álvaro-Meca A, González-López A, Gil de Miguel A. Herpes zoster hospitalizations of patients with chronic illnesses in Spain, 1998-2004. Vacunas. 2011;12(3):95-101.

54. Gil-Prieto R, Walter S, Gonzalez-Escalada A, Garcia-Garcia L, Marin-Garcia P, Gil-de-Miguel A. Different vaccination strategies in spain and its impact on severe varicella and zoster. Vaccine. 2014;32(2):277-83.

55. Gonzalez Chiappe S, Sarazin M, Turbelin C, Lasserre A, Pelat C, Bonmarin I, et al. Herpes zoster: Burden of disease in France. Vaccine. 2010;28(50):7933-8.

56. Lionis CD, Vardavas Cl, Symvoulakis EK, Papadakaki MG, Anastasiou FS, Antonopoulou MD, et al. Measuring the burden of herpes zoster and post herpetic neuralgia within primary care in rural Crete, Greece. BMC Fam Pract. 2011;12(1):136

57. Loncar Z, Mestrovic AH, Bilic M, Taksic I, Mickovic V. Quality of pain in herpes zoster patients Kvaliteta boli kod pacijenata oboljelih od herpes zostera. Coll Antropol. 2013;37(2):527-30.

58. Lukas K, Edte A, Bertrand I. The impact of herpes zoster and post-herpetic neuralgia on quality of life: patient-reported outcomes in six European countries. Zeitschr Gesundheitswissenschaften = J Public Health. 2012;20(4):441-51.

59. Mesquita M, Froes F. Hospital admissions for Herpes Zoster in Portugal between 2000 and 2010 Internamentos hospitalares por Herpes Zoster em Portugal entre 2000 e 2010. Acta Med Port. 2013;26(5):531-6.

60. Moore L, Remy V, Martin M, Beillat M, McGuire A. A health economic model for evaluating a vaccine for the prevention of herpes zoster and post-herpetic neuralgia in the UK. Cost Effect Resour Allocation: C/E. 2010;8:7.

61. Morant-Talamante N, Diez-Domingo J, Martinez-Ubeda S, Puig-Barbera J, Aleman-Sanchez S, Perez-Breva L. Herpes zoster surveillance using electronic databases in the Valencian Community (Spain). BMC Infect Dis. 2013;13(1):463.

62. Mordarski S, Lysenko L, Gerber H, Zietek M, Gredes T, Dominiak M. The effect of treatment with fentanyl patches on pain relief and improvement in overall daily functioning in patients with postherpetic neuralgia. J Physiol Pharmacol. 2009;60 suppl 8:31-5.

63. Nilsson J, Cassel T, Lindquist L. Burden of herpes zoster and post-herpetic neuralgia in Sweden. Value Health. 2013;16(7):A347.

64. Pierik JG, Gumbs PD, Fortanier SA, Van Steenwijk PC, Postma MJ. Epidemiological characteristics and societal burden of varicella zoster virus in the Netherlands. BMC Infect Dis. 2012;12:110.

65. Rabaud C, Rogeaux O, Launay O, Strady C, Mann C, Chassany O, et al. Early antiviral treatment fails to completely prevent herpes-related pain. Med Mal Infect. 2013;43(11-12):461-6.

66. Rehm S, Binder A, Baron R. Post-herpetic neuralgia: 5\% lidocaine medicated plaster, pregabalin, or a combination of both? A randomized, open, clinical effectiveness study. Curr Med Res Opin. 2010;26(7):1607-19.

67. Schiffner-Rohe J, Köster I, Beillat M, Lilie H, Schubert I. Resource consumption and health care costs of herpes zoster and postherpetic neuralgia in Germany. Gesundheitsökonomie Qualitätsmanagement. 2011;16(04):216-23.

68. Scott FT, Leedham-Green ME, Barrett-Muir WY, Hawrami K, Gallagher WJ, Johnson R, et al. A study of shingles and the development of postherpetic neuralgia in East London. J Med Virol. 2003;70 Suppl 1:S24-30.

69. Sicras-Mainar A, Navarro-Artieda R, Ibáñez-Nolla J, Perez-Ronco J. [Incidence, resource use and costs associated with postherpetic neuralgia: a population-based retrospective study]. Rev Neurol. 2012;55(8):449-61. 
70. Souliotis K, Lionis C, Papadakaki M, Papageorgiou M, Tsiaousi I, Bersimis S. The economic burden of herpes zoster on patients visiting primary care settings in Greece-Results from a multicentre study in Crete. Eur Geriatr Med. 2013;4:S117-8.

71. Studahl M, Petzold M, Cassel T. Disease burden of herpes zoster in Sweden - predominance in the elderly and in women - a register based study. BMC Infect Dis. 2013;13(1):586.

72. Szucs TD, Kressig RW, Papageorgiou M, Kempf W, Michel JP, Fendl A, et al. Economic evaluation of a vaccine for the prevention of herpes zoster and post-herpetic neuralgia in older adults in Switzerland. Hum Vaccine. 2011;7(7):749-56.

73. Ultsch B, Siedler A, Rieck T, Reinhold T, Krause G, Wichmann O. Herpes zoster in Germany: quantifying the burden of disease. BMC Infect Dis. 2011;11:173.

74. van Hoek AJ, Gay N, Melegaro A, Opstelten W, Edmunds WJ. Estimating the cost-effectiveness of vaccination against herpes zoster in England and Wales. Vaccine. 2009:27(9):1454-67.

75. Volpi A, Gatti A, Serafini G, Costa B, Suligoi B, Pica F, et al. Clinical and psychosocial correlates of acute pain in herpes zoster. J Clin Virol: Offic Publ Pan Am Soc Clin Virol. 2007;38(4):275-9.

76. Volpi A, Gatti A, Pica F, Bellino S, Marsella LT, Sabato AF. Clinical and psychosocial correlates of post-herpetic neuralgia. J Med Virol. 2008;80(9):1646-52.

77. Weinke T, Edte A, Schmitt S, Lukas K. Impact of herpes zoster and post-herpetic neuralgia on patients' quality of life: a patient-reported outcomes survey. Zeitschr Gesundheitswissenschaften = J Public Health. 2010;18(4):367-74

78. Organization WH. Active ageing: a policy framework. 2002.

79. Galluzzi KE. Management strategies for herpes zoster and postherpetic neuralgia. J Am Osteopath Assoc. 2007;107(3 Suppl 1):S8-13.

80. Whitley RJ, Volpi A, McKendrick M, Wijck A, Oaklander AL. Management of herpes zoster and post-herpetic neuralgia now and in the future. J Clin Virol: Offic Publ Pan Am Soc Clin Virol. 2010;48 Suppl 1:S20-8.

81. Volpi A, Gross G, Hercogova J, Johnson RW. Current management of herpes zoster: the European view. Am J Clin Dermatol. 2005;6(5):317-25.

82. Brisson M, Pellissier JM, Camden S, Quach C, De Wals P. The potential cost-effectiveness of vaccination against herpes zoster and post-herpetic neuralgia. Hum Vaccine. 2008;4(3):238-45.

83. Pickering $G$, Leplege A. Herpes zoster pain, postherpetic neuralgia, and quality of life in the elderly. Pain Pract: Offic J World Inst Pain. 2011;11(4):397-402.

84. Mortensen GL. Perceptions of herpes zoster and attitudes towards zoster vaccination among 50-65-year-old Danes. Dan Med Bull. 2011;58(12):A4345.

85. Eurostat: Ageing Charaterises the Demographic Perspectives of the European Societies. Statistics in Focus Available at: http://ec.europa.eu/eurostat/en/web/ products-statistics-in-focus/-/KS-SF-10-001 2008.

86. Yawn BP. Post-shingles neuralgia by any definition is painful, but is it PHN? Mayo Clin Proc Mayo Clin. 2011;86(12):1141-2.

87. Singhal PK, Makin C, Pellissier J, Sy L, White R, Saddier P. Work and productivity loss related to herpes zoster. J Med Econ. 2011;14(5):639-45.

88. Drolet M, Levin MJ, Schmader KE, Johnson R, Oxman MN, Patrick D, et al. Employment related productivity loss associated with herpes zoster and postherpetic neuralgia: a 6-month prospective study. Vaccine. 2012;30(12):2047-50

\section{Submit your next manuscript to BioMed Central and take full advantage of:}

- Convenient online submission

- Thorough peer review

- No space constraints or color figure charges

- Immediate publication on acceptance

- Inclusion in PubMed, CAS, Scopus and Google Scholar

- Research which is freely available for redistribution 